\title{
Cultural Constraints on the Selection of Literary Translation Texts in Modern China
}

\author{
Wei Lou \\ College of Foreign Languages, Qingdao University of Science and Technology, Qingdao, China \\ E-mail: cindylw@163.com
}

\begin{abstract}
Translation is always an activity which involves socio-cultural factors. In this essay, the author tries to figure out how the social needs and prevailing literary norms affect the selection of literary translation texts in modern China.
\end{abstract}

Index Terms - social needs, literary norms, selection, literary translation texts

\section{INTRODUCTION}

After the First and Second Opium War, some advanced Chinese intellectuals found that the key to the powerful resistance to foreign intrusion was not only to learn new technology, but also to import new ideas and values from the West. Besides, they felt that Chinese culture was radically deficient and that it was impossible for people of old thought to exercise a new institution, so the complete awakening of national character was required. (Liang Qichao,1983: 834) It was the first time for them to realize that China's backwardness was not due to underdeveloped industry, nor poor political system, but the backwardness of culture, the ignorance of people's minds, and the deficiency of national character. Consequently they began to criticize traditional Chinese culture sharply and introduce western spiritual culture, namely, the literary works of western countries. So the reason why those intellectuals went to great lengths to introduce those western works into China at this period of the history was that the then society needed translation by which new thoughts and ideas were imported, just like professor Wang Zuoliang pointed out, "Climax does not come all of a sudden, and the prosperity of translation is because of practical needs" (Wang Zuoliang, 1995:11-13). However, among millions of foreign literary works, what kinds of texts were selected while others were not? Myriam Carr argued that "selection is rarely innocent or random--- there is always a reason for translating". He explained, "two examples would be translations from Greek into Syrian and Arabic in the nineteenth century where Greek philosophy was translated but not Greek literature because it did not fulfill a need in the target culture". This is true of the literary translation of modern China (Gao Huiqun,Wu Chuangun,1992:54-56). Actually, the translation procedure involves a myriad of choices or decisions, for which some reasons always count. Kong Huiyi (Eva Hung), a famous scholar, who has made a lot of contributions to the study of cultural influence on various aspects of translation, pointed out that when a translation initiator (He may be a translator, a publisher or an editor.) introduces foreign works into the target culture, the success of the translated works in the target culture are subject to two preconditions: first, there must be a need for such kind of works; Second, the norms in the source culture can be set as models in the target culture. When these two are taken into consideration, works will be translated into a target culture in great numbers. (Kong Huiyi,1999: 9 ) So in this essay, the author tries to figure out what socio-cultural factors influenced the selection of translation texts how they worked in modern China.

\section{SOCIAL NEEDS}

The demands and needs for translation arose when existing conditions were inadequate or even absent to accomplish a certain purpose. A vacuum appeared and translation stepped in to fill the gap...Broadly one can see translation as a response to the needs and demands of society in the Chinese record: Buddhist translation can be seen as satisfying spiritual needs; the technological translation of the seventeenth century has propelled material advancement; and translation of the social sciences and humanities has helped ideological evolution and revolution at periods when China has been in great social transition. (Lin Kenan as qtd. by Tymoczko, Maria., and Gentzler, Edwin, 2002:172) Likewise, the literary translation of modern China was to meet the demands and needs of the then social situation. However, such demands and needs are always changing with the social and political situation, rather than remaining static. During the Late Qing Dynasty and the early Republic of China, the main purpose of translating foreign literary works was to improve the backward traditional culture, enlighten people's ignorant minds, and overcome the deficiency of national character; In the period of the May 4th Movement, the chief task of the Chinese people was to struggle against feudalism and imperialism, therefore the selection of literary works changed accordingly and anti-imperialism as well as anti-feudalism became the theme of most translated works at that time; whereas since the 1930's, China was at a critical time when she was in danger of being annexed. In order to awaken people's consciousness of the national crisis and inspire them to fight for their motherland, translated literary works focused on topics reflecting national 
independence and the like. In the following paragraphs, the author is going to further discuss how social demands and needs restrain the selection of texts in two perspectives: political needs and the readers' needs. Since in this period, the political factors played a decisive role, the author will put more words on this facet.

\section{A. Political Needs}

In selecting translation texts, politics has always played the most important and decisive role. Through translation, foreign literary works are introduced into China and meet China's political needs. Therefore, the selection of the texts is not at random. The author is going to clarify this problem from two aspects: selection of subject and selection of style.

1. Selection of Subject

To enlighten people's mind is one of the characteristics in the subject selection during this period, especially from the late Qing Dynasty to the Early Republic of China. For example, Yan Fu bore a clear-cut aim in his mind when he translated the famous Evolution and Ethics. He attempted to "strengthen people's power, to enlighten people's mind, and to refresh people's virtue" as well as to "cure people's ignorance". His translated version of Evolution and Ethics is regarded as the morning bell to awaken the whole nation. (Wang Kefei,1998:301)

During the period of the May Fourth Movement in China, one of the characteristics of translation is the great importance attached to literature of impaired nations. For example, Lu Xun and Zhou Zuoren saw literary translation as a means of altering China's subordinate position in international relations, so they gravitated toward foreign countries that occupied a similar position, but whose literature threw off their minority status to achieve international recognition. Their Anthology of Foreign Fictions contained mostly Russian and Eastern European short stories, including several from some unnoticeable countries at that time like Poland and Finland. The translators selected the subject in the hope that the readers could know about the cultural, political and economic situation in those countries whose people were struggling against their oppressors in order to get liberty and democracy, thus could strengthen Chinese people's confidence in the victory against western imperialists. Lu Xun stated the reason of his preference in one of his books Why did I Take Up Novel Writing:"What I'm trying to seek are works of shouts and resistance, which naturally lead me to think of East Europe. That's why most of the works I read are from Russia, Poland and some small Balkan countries." (Wang Kefei,1998:197 )

Around 1919, many works of Marxism and dramas of Realism from North and West Europe were introduced and more works from East Europe and Russia were translated into China. According to the statistics of Historical Data Index of Chinese New Literature, during the eight years after the May 4th Movement, foreign literary works translated into Chinese amounted to one hundred and eighty-seven, among which Russian works reached sixty-five, making up more than one third. Qu Qiubai, in his Preface to Collection of Russian Classical Short Stories, pointed out that the reason why Russian literature was in vogue for a time was that the success of the October Revolution in 1917 increased Chinese people's confidence in pursuing a sovereign remedy to save their country and they were eager to have a clear idea of the Russian revolution and draw experience and strength from Russian literary works. (Chen Yugang,1989: 113-114) Since Russian literature was so significant to China, Lu Xun even compared the translating of Russian literature to Prometheus' stealing fire for human beings and to the smuggling of ammunition for the rebelling slaves.

The political attitudes of the literary works and the original author's viewpoints have always been considered the criteria of whether or not the texts will be introduced and translated in China. Zheng Zhenduo pointed out, in his Influence of Late Qing Novels on New Literature, that all translators in late Qing Dynasty preferred to use the ideas and thoughts in foreign novels as the tool of political reform (Wang Xiaoyuan, 1999: 11). To meet the needs of the then political situation, works of certain authors secure a higher status in the target culture than in the original and are particularly favored by publishers and translators.

The British romantic poet Byron is a good example. His The Isles of Greece was rendered successively by such famous scholars and poets as Liang Qichao, Su Manshu, Ma Junwu, and once became the rage in modern China. No other foreign poets were as popular as Byron during this period. Besides the moving lines of the poem itself, a more important reason for this phenomenon lies in the revolutionary theme embodied in the poem, which is badly needed by the social situation. At that time, China was in danger of being conquered by foreign invaders, and many ambitious and patriotic young people and liberators were determined to overthrow the deteriorated Qing Dynasty and fight against the foreign invasion. In this poem, Byron sighed with regret that the once prosperous ancient Greece had become a slave to outsiders, which was quite similar to the situation in China at that time. That was why his poems could find an intensive echo in most patriotic Chinese young people and was translated for several times. In contrast to Byron, another British romantic poet Wordsworth was not as well known in China, though the literary value of his works was considered much higher than that of Byron's in the western countries. That was because most of his poems were about country life, which were of no practical value to modern China.

In the period of the May 4th Movement, Ibson's drama was translated into Chinese and was well received. It is not that the drama is artistically accomplished but that the work advocates emancipation and independence of one's character as well as free marriage. These ideas meet the demands of the period, namely, liberation of man. This is also true of other cases. Sándor Petöfi doesn't enjoy a high reputation outside of his own country, but he is well-known in China for his poem Ode to Freedom which has not much literary value, though. The popularity of his poem lies in the theme which happens to satisfy the political situation in which Chinese people were longing for freedom against the western imperialist powers and feudal oppression. 
Translators in this period gave priority to political needs. This inclination affected the selection of texts to be translated. If a piece of literary work suited the political needs of the time, it would be introduced to the target culture even though it might not have artistic values. The translated work might secure a higher status than its original form.

If making a general observation of the literary translations in modern China, one can find that literary texts with such subjects as mind enlightening, patriotism inspiring, anti-imperialism, and anti-feudalism are particularly favored by the translators and publishers, which reflects the social and political needs of the society.

2. Selection of Styles

In Chinese literary history style was viewed in a strictly hierarchical order. Novels and plays were generally regarded as popular and vulgar literary forms only for pastime leisure, not appealing to refined taste, and containing nothing educational and important, while poetry and prose were looked on as the most important forms. However, in the period of late Qing Dynasty, a boom appeared in writing and translating novel, which originated from the deep social and national crises of China in the second half of the nineteenth century. Through the advocacy of Liang Qichao and others, unprecedented attention was paid to novels, especially translated novels. At that time a large number of translated fictions were published. According to A Ying, the leading authority on the late Qing literature, there were 420 originals and 587 translated works published from 1875 to 1911, making a total of 1,007 works. Translation accounts for approximately 58\%. (Tarumoto 1998: 38) And the Japanese scholar Tarumeto Teruo's analyses of all presently available sources shows that there were 1,288 originals and 1,016 translated versions from 1840 to1911. (ibid: 39) Also the kinds of novel were enlarged through translating. There were eight kinds of novels, including political novels, educational novels, nihilist novels, historical novels, social novels, science novels, detective novels and love novels. (Cheng Xiangzhang, 1993: 69) In a word, The status of fiction rose drastically and translated novels constituted an important part in publications of that period. So what resulted in the boom of translated novels? So why did Liang Qichao try hard to enhance novels' position in traditional Chinese literature since he was a statesman more than a litterateur? How did the cultural factors affect the translators' selection of literary styles? It is because the conditions for bringing translated novels into China in the last decade of the Qing Dynasty were most favorable. At that time China was suffering from serious foreign aggression and partition by Western nations, which appeared imminent; internally, there was strong urge for reform. Kang Youwei and Liang Qichao initiated a reform. At the beginning of their reform movement, they had their eyes primarily on the Emperor Guang Xu and his ministers; later, they focused on the gentry and average educated men. The failure of the 1898 Hundred-Day Reform led to the rise of revolutionary ideas, and the main target audience of advocacy for reform shifted towards the lower classes. The change of their objects naturally resulted in the change of the way reform advocates presented their ideas. It seemed that the more popular and simpler the way was the better and thus fiction was the best choice to enlighten the general population. So Liang Qichao deliberately reversed the traditional idea and advocated that fiction was 'the best among all forms of literature'.(Wang Hongzhi, 2000:4) For the first time, Chinese readers were told that fiction had greatly helped the political development of Europe, American and Japan. Liang Qichao was deeply influenced by a piece of writing by his teacher KangYouwei: Those who are barely literate may not read the Classics, but they all read fiction. Hence, the Classics may not be able to teach them, but fiction will. Orthodox history may not affect them, but fiction will. The works of philosophers may not enlighten them, but fiction will. The laws may not regulate them, but fiction will.(Wang Hongzhi, 2000:173-174 )Here Kang Youwei elaborated and even exaggerated fictions' political function in influencing the common people. Political novel, combining the two elements of politics and fiction, was naturally the most appropriate choice. Hence political novels soon became one of the most important categories of fictions at that time.

At the very beginning of his 'Preface to the Translation and Publication of Political Novel', Liang Qichao stated clearly the enormous cultural and political functions of fictions in changing one country and that 'fiction is the spirit of the nation': In the past, when European countries began their reform movements, outstanding scholars, men of superior knowledge and men of principle often used novels to write about their personal experiences and to express their ideas and political views. Thus in schools, teachers would carry these novels about with them and talk about them when they had leisure. Even soldiers, merchants, peasants, artisans, chauffeurs, grooms, children and women would all carry them about and talk about them. Very often, the thinking of the whole nation changed with the publication of one book. The contribution of political novel to the daily progress in the politics of America, England, Germany, France, Austria, Italy and Japan has been tremendous. A famous person in England once said, 'fiction is the spirit of the nation'. Isn't this most correct? (Wang Hongzhi,2000:178)He even held the view that: To enlighten the people of a nation, it is necessary to renew its novels. Therefore, to regenerate its morality, it is a must to renew its novels; to renovate its religion, it is a must to renew its novels; to reform its politics, it is a must to renew its novels; to update the customs, it is a must to renew its novels; to renew the knowledge and skills, it is a must to renew its novels; to refresh people's minds and characters, it is a must to renew its novels. (Liang Qichao, On Relationship between Novels and the Governance of the Masses)(Wang Hongzhi,2000:37)

As far as fiction itself is concerned, the Italian writer and translator Virginia Ugo Tarcheti (1839-1869) argues that novel is an imaginary resolution to social contradictions and a genre that fictively compensates for the wretched realities and makes a renewal of social life by representing a marvelous world wherein hierarchical social relations are resolved (Venuti, 1995: 152). From the very beginning Kang Youwei, Liang Qichao and other reformers made use of novels, especially translated novels, as a political tool to express and publicize the politics and enlighten the masses. Those 
works were evaluated by them from eyes of thinkers or politicians instead of eyes of artists, so what they valued most about literary works were their drum beating functions rather than their artistic values.

In sum, the selection of literary works in this period was closely linked with the social needs of the society, which resulted in the emphasis on the function the texts and the neglect of aesthetic values of the works. In a word, the literary works were treated primarily as a tool for social enlightenment and political reform not for their artistic value.

\section{B. Readers'Needs}

In late Qing Dynasty, the advocator of translating novels into China hoped that they could change the social norms and remold the national character. However the objects they were confronted were the conservative masses that had received little education and know nothing about the outside world, let alone the developing trend of the future society. Under such a practical condition, they had to translate popular literary works to meet the masses' needs.

Before the May 4th Movement, though a lot of literary works were translated, more than $90 \%$ of them were secondary works written by secondary or infamous writers and merely less than $10 \%$ of them were masterpieces. So why did the translators make such choices? The main reason for this phenomenon could be attributed to the low educational level of the readers. Most common people received little education and thus had little knowledge of western countries and their people, let alone western literature. Therefore the main task of literary translation at that time was to help them understand the customs and traditions, way of life and values of western people. That was why when selecting literary texts, translators laid more emphasis on the introduction of new ideas and concepts of western civilizations than on the literary values of the opuses. What's more, the weak literary consciousness of some translators was another important reason, which will not be given further discussions here.

Besides, this period saw the translation of a great number of detective fictions which became the most popular form of all fictions. The popularity of detective novels was largely due to the novelty of both the content and form. New products of science and technology such as trains, subways and telegraphs were often introduced in this kind of novels, which greatly aroused the curiosity and interest of the common Chinese readers who were eager to know about the outside world. And this kind of novels provided the very thing they expected. As members of the target culture, the masses' expectations share the characteristics of the culture in a way. Only when the translated literary works conform to the expectations or demands of the populace in the target culture, will they be accepted by the target readers; otherwise they will be left alone or even rejected. However, the target culture is always changing and the changes of the target cultural context will result in the changes of the populace's expectations at a certain time. Therefore the selection of texts to be translated has to change accordingly to adapt to their expectations. Just as Vermeer understands, translation is "to produce a text in a target setting for a target purpose and target addressees in target circumstances" (Nord, 1997: 12).

Generally speaking, readers' demands for translation are always "right". These demands and needs have to negotiate the power of those in charge, however. As a result, some needs are satisfied, some ignored, and others ruthlessly suppressed.

\section{PREVAILING LITERARY NORMS}

Relatively speaking, the influence of literary factors on text selecting in modern China is much less important than that of social and political factors since the major purpose of the literary translation at this period is to fulfill the political need rather than literary appreciation. Nevertheless, the prevailing literary norms, as part of the target culture, inevitably affect the selecting of literary texts. So it is also worth discussing here.

The literary norm of the target culture is not an isolated element but closely connected with other elements in the same culture. According to Andre Lefevere, the literary norm will be the touchstone used by teachers, critics, and others to decide what is in and what is out (Lefevere, 1992: 36). Therefore, only certain kinds of texts, which will prove familiar to the receiving culture, come to be translated. So the literary norm actually is deeply rooted in the culture it belongs to and reflects the distinct characteristics of its culture. The selecting of literary texts in modern China is also unexceptionally limited by the prevailing literary norm of the time, which can help to explain why the translation of poetry was limited and some new literary forms didn't become prosperous.

Compared with the large amount of novels translated, the translation of poetry at that time is quite limited. This is mainly because the western poetry could not find a carrier in traditional Chinese literature. Poem translation was considered "impossible" by many translators at that time since classical Chinese poetry was restricted by rhyme scheme, form and structure and it was really hard to translate a western poem into proper Chinese in the aspects of content and form, meaning and sound. In addition, as discussed above, the function of literary works at that time was very practical since it was used to meet the social needs. Compared to novel, poetry is a refined literary form that is not suitable for propaganda, so the translation of western poetry is relatively small in quantity.

During the boom of literary translation in modern China, few works of stream of consciousness were introduced into China, though stream of consciousness was a primary literary form of Western literature. However, this doesn't mean that the Chinese literary world didn't concern itself with this new literary form; instead, at the beginning there were quite a lot of introductions and comments on Eugene O'Neill, James Joyce, Virginia Woolf and William Faulkner and their works of stream of consciousness published in literary periodicals. At the same time, some Chinese writers like Lu 
Xun, Guo Moruo and Yu Dafu applied this new literary technique to their composition. (Wang Jiankai, 2003:11) Nevertheless, stream of consciousness didn't become prosperous in China but remained stagnant and even left no trace. This was due to the fact that stream of consciousness did not conform to China's literary convention which was dominated by realism and romanticism. It was a strange literary form to Chinese readers who found it hard to understand and unwilling to accept. Besides, since China was encountered with severe national crisis at that time, what the literary world cared most was the content of the works rather than their forms. While most works of stream of consciousness focused on the development of characters' feelings and thoughts which did not conform to the then literary context.

Aestheticism shared the same fate in modern China. During the May 4th Movement, there once appeared an 'Oscar Wilde Craze' in China's literature because the traitorous nature of aestheticism struck a responsive chord in the anti-tradition and anti-feudalism Chinese literary circles. However this new style of literature didn't last long but vanished away in a short time. If we put the phenomenon in the overall literary context, it is not difficult to find out that what aestheticism seeks is 'pure beauty' and 'pure art', while the major tenet of Chinese modern literature was 'for life' rather than 'for pure art'. Therefore, aestheticism couldn't find a proper place in Chinese modern literature and withered away.

Although literary norms didn't exert influence as great as the political factors on literary translation in modern China, its influence can't be overlooked.

\section{SUMMARY}

There is no doubt that the selection of texts in modern China constrained by the socio-cultural factors of the society. The need of the then society was the main reason, especially the political needs which played the most decisive role and governed the selection of subject, style and other elements of the translated literary works. The subjects of most literary works tended to enlighten people's mind, awaken people's consciousness of anti-imperialism and anti-feudalism and to inspire people to resist the oppression from western imperialists and domestic feudalists, all of which were closely related to the then political situation. The most popular genre at the time was novel since the main object of literary translation was the masses and one of the main purposes of translation was to educate the masses and improve their literacy level, so novel, the most popular and acceptable literary form was considered as a tool to fulfill this function. In addition, the literary norms also influenced the translator's and publisher's preference when selecting literary texts. If the translated works did not conform to the prevailing Chinese literary conventions, they would not attract attention from the majority or they might even be rejected.

\section{REFERENCES}

[1] Gao huiqun \& Wu chuangun. (1992). On Biography of Yan fu. Shanghai: Foreign Language Education Press.

[2] Gentzler, Edwin. (1993). Contemporary translation theories. New York: Routledge Inc.

[3] Kong huiyi. (1999). Translation, Literature, Culture. Beijing: Peking University Press.

[4] Lefevere, Andre. (1992). Translating, Rewriting and the Manipulation of Literary Fame. London: Routledge.

[5] Wong Wang-chi, Lawrence. (1998). 'The Sole Purpose Is to Express My Political Views: Liang Qichao \& the translation \& writing of political novels in the late Qing.' In Translation \& Creation: readings of Western literature in early modern China, 1840-1918. Ed. David Pollard. Philadelphia: John Benjamins Publishing Co.

[6] Wong Wang-chi. (2000). In Translation \& Creation: readings of Western literature in early modern China. Beijing: Peking University Press.

[7] Venuti, Lawrence. (1998). The Scandals of Translation: towards and ethics of difference. London \& New York: Routledge.

[8] Tarumoto, Teruo. (1998). A statistical Survey of Translated Fiction: 1840-1920. In Translation \& Creation: readings of Western literature in early modern China, 1840-1918. Ed. David Pollard. Philadelphia: John Benjamins Publishing Co. PP.37-42.

[9] Nord, Christiane. (1997). Translating as a Purposeful Activity: Functionalist Approaches Explained. Manchester: ST. Jerome Publishing.

[10] Tymoczko, Maria., and Gentzler, Edwin. (2002). Translation and Power. Amberst and Boston: University of Massachusetts Press.

[11] Wang Kefei. (1998). Cultural History of Translation. Shanghai: Shanghai Foreign Language Education Press.

[12] Wang Zuoliang. (1995). Translators of the Period of British Renaissance. Foreign Language Teaching and Research, Volume 1, 11-13.

[13] Wang Xiaoyuan. (1999). The Interaction between Ideology and Literary Translation. Chinese Translators Journal, volume 2, 11-14

[14] Chen Yugang. (1989). History of Chinese Translation. Beijing: China Translation and Publishing Corporation.

[15] Cheng Xiangzhang. (1993). On Styles of Translated Novels in Modern China. Foreign Literature Studies, volume 1, 69-74.

[16] Liang Qichao. (1983). The Evolution of China in Half a Century. Collected Works of Liang Qichao. Beijing: People's Literature Press.

[17] Wang Jiankai. (2003). The Translation of British and American Literary Works in China: 1919-1949. Shanghai: Shanghai Foreign Language Education Press. 
Wei Lou was born in Qingdao, China in 1974. She received her M.A. degree in Foreign Linguistics and Applied Linguistics from China Ocean University, China in 2004.

She is currently a lecturer in the College of Foreign Languages, Qingdao University of Science and Technology, Qingdao, China. Her research interests include translation theory and college English teaching. 